\title{
RETROACTIVE ADMINISTRATIVE DECISIONS
}

\section{RAOUL Berger $\dagger$}

While courts have been striking the shackles of retroactivity, the administrative process, fondly viewed as a progressive development in the art of government, ${ }^{1}$ anomalously lays claim to, and often callously exercises, a retrospective adjudicatory power which is the product of discredited assumptions. Decisional retroactivity, which is associated with inflexible judicial habit, is paradoxically embraced by administrative agencies in the name of flexibility. ${ }^{2}$

Judicial retroactivity was an outgrowth of the "declaratory theory" that judges never make law, they merely discover it. Consequently an overruled decision was "never the law" but "only a failure at true discovery," 3 and in this light retrospective operation was understandably deemed to be a "logical necessity." 4 Austin justly labeled this theory a "childish fiction," 5 and he is but one of a roster of great names that includes Bentham, Holmes, Pollock and Cardozo. ${ }^{6}$ Now

$\dagger$ A.B. 1932, University of Cincinnati. J.D. 1935, Northwestern University. LL.M. 1938, Harvard University. Chairman, ABA Section on Administrative Law, 1961-62.

1 Landis, The Administrattve Process 1-2, 5, 46 (1938) ; cf. 1 Davis, AdminisTRATIVE LAW TREATISE \$ 1.05, at 34-43 (1958) [hereinafter cited as Davis] ; GeILHoRN \& Byse, Administrative Law: Cases and Comments 2-6, 9 (4th ed. 1960).

2 Leedom v. International Bhd. of Elec. Workers, 278 F.2d 237, 243 (D.C. Cir. 1960); Shawmut Ass'n v. SEC, 146 F.2d 791, 796-97 (1st Cir. 1945).

3 Linkletter v. Walker, 381 U.S. 618, 623-24 (1965); see Berger, Estoppel Against the Government, 21 U. CHI. L. REv. 680, 703 (1954); Kocourek \& Koven, Renovation of the Common Law Through Stare Decisis, 29 InL. L. REv. 971, 985-87 (1935).

4 Snyder, Retrospective Operation of Overruling Decisions, 35 ILL. I. REv. 121, $122(1940)$.

52 Austin, Jurisprudence 655 (4th ed. Campbell 1873).

6 See Berger, stpra note 3 , at 703 nn.142 \& 144 . Cardozo was an early proponent of prospective operation where a retroactive judicial declaration was inexpedient. 55 N.Y. STATE BAR Ass'N REP. 263, 295-97 (1932). See also the remarks of Judge Jerome Frank in Aero Spark Plug Co. v. B.G. Corp., 130 F.2d 290, 298 (2d Cir. 1942) (concurring opinion). For a review of the literature see Levy, Realist Jurisprudence and Prospective Overruling, 109 U. PA. L. REv. 1 (1960); Note, 71 YaLe L.J. 907 (1962).

Professor Kocourek had concluded in 1935 that "the rule of retrospection is gradually losing ground in nearly all fields of law ... . The idea of retrospection is contrary to the basic assumption of law as a system for the regulation of social behavior." Kocourek \& Koven, supra note 3, at 997. Justice Schaefer recently wrote that since Great No. Ry. v. Sunburst Oil \& Ref. Co., 287 U.S. 358 (1932) (see text accompanying notes 141-43 infra), "state courts have, with increasing frequency, coupled the overruling of an earlier decision with an announcement that the new rule will not be given retroactive effect. The primary purpose, of course, is to avoid frustration of justifiable reliance upon the old rule . . Schaefer, Chief Justice Traynor ard the Judicial Process, 53 CaLIF. L. REv. i1, 17 (1965). 
the Supreme Court, in Linkletter v. Walker, ${ }^{7}$ has also concluded that retroactivity is not a categorical imperative.

Behind Linkletter lie factors that have played all too small a role in the evaluation of administrative retroactivity. Those factors have been so often stressed in studies of legislative and judicial retroactivity that a quick summary will suffice. Retroactivity, summed up $\mathrm{Mr}$. Justice Rutledge, "is not favored in law. There are few occasions when retroactivity does not work more unfairly than fairly. Congress, the state legislatures and the courts apply the principle sparingly, even where they may." 8 Sparing application strives also to protect persons who have acted in reliance upon what they have justifiably believed to be existing law, and to preserve stability in the operation of government and in contractual and property relations. ${ }^{9}$

Of reliance, ${ }^{10}$ the Supreme Court said in 1872 , its protection is based "upon the highest principles of justice. Parties have a right to contract, and they do contract in view of the law as declared to them when their engagements are formed. Nothing can justify . . . hold-

7381 U.S. 618, 628-29 (1965). Relief from a state conviction based upon unconstitutionally obtained evidence was denied, and Mapp v. Ohio, 367 U.S. 643 (1961), which invalidated such state convictions, overruling Wolf v. Colorado, 338 U.S. 25 (1949), was limited to prospective operation.

A vigorous attack upon Linkletter by Professor Paul J. Mishkin, Foreword: The High Court, the Great Writ, and the Due Process of Time and Laze, 79 Harv. L. REv. 56 (1965), is based in considerable part on the premise that the Blackstonian "declaratory theory" is a valuable symbol which contributes heavily to respect for the Court and conduces to acceptance of its rulings. Id. at 62-70. In emphasizing the values inherent in the theory that judges do not make but rather discover the "law," Professor Mishkin takes full account of the "realist" argument to the contrary. Doubtless his views will generate controversy, as may be surmised from the earlier controversial literature about the Linkletter problem, cited id. at 57 n.6. To comment on this controversy would require a full-length article, so that for present purposes it must suffice that 1) Professor Mishkin acknowledges that the Linkletter view that courts have power "to make new law effective for the future only" follows "the general pattern set by prior writing on the subject," id. at 58 , and 2 ) his analysis is largely cast within the framework of constitutional issues in the Supreme Court, and there are intimations that issues of "common and statutory law in courts generally" may be distinguishable, id. at 71 , that "outright prospective limitation may be justified" in circumstances involving "contract or property rights," id. at 70 n.47, and that "even Blackstonian retroactivity need not be given unintelligent, inexorable effect." Id. at 77 n.70. The views herein expressed have ample play within those exceptions.

8 Addison v. Holly Hill Fruit Prods., Inc., 322 U.S. 607, 641 (1944) (dissenting opinion in which Black and Murphy, J.J., joined); see also Claridge Apartments v. Commissioner, 323 U.S. 141, 164 (1944); Leedom v. International Bhd. of Elec. Workers, 278 F.2d 237, 240 (D.C. Cir. 1960).

9 Currier, Time and Change in Judge-Made Law; Prospective Overruling, 51 VA. L. REv. 201, 234-36 (1965); Hochman, The Supreme Court and the Constitutionality of Retroactive Legislation, 73 HARv. L. REv. 692-93 (1960); Kocourek \& Koven, supra note 3 , at $972,981-82$; Snyder, supra note 4 , at 146-48.

10 "The community have a right to regard [a decision made upon solemn argument and mature deliberation as an] ... exposition of the law, and to regulate their actions and contracts by it." 1 KENT, COMMENTARIES oN AMERICAN LAW *476 (11th ed. Comstock 1867) ; Kocourek \& Koven, supra note 3, at 972; Snyder, supra note 4, at 148; see HART, THE CONCEPT of LAW passim (1961). 
ing them to any other rule." 11 For "men naturally trust in their government, and ought to do so, and they ought not to suffer for it." 12 "Certainty" of the law powerfully contributes to "stability," and, said Bacon, "certainty is so essential to law, that law cannot even be just without it." 13 It was to avoid retroactive unfairness and disruption of stable relations that the courts, mistakenly conceiving that prospective change was beyond their power, clung tightly to stare decisis. ${ }^{14}$ Though stare decisis is no longer an "inexorable command," it remains "ordinarily a wise rule of action." 15 This is not to suggest that agencies are less prone to heed precedent than courts but that administrative departures having undesirable retroactive effects have been too lightly condoned. ${ }^{16}$

To posit that agencies, like courts, have or should have discretion to make decisions retroactive ${ }^{17}$ is only the beginning. If judicial dis-

11 Olcott v. Supervisors, 83 U.S. (16 Wall.) 678, 690 (1872). Cardozo also stressed the "necessity of avoiding retrospective changes that would frustrate the reasonable expectations of well-intentioned men." 55 N.Y. STATE BAR Ass'N REP. 263,294 (1932). He did not insist upon proof of such reliance but stated of an existing rule that "men have accepted it as law, and have acted on the faith of it. At least, the possibility that some have done so, makes change unjust, if it were practicable, without saving vested rights." Cardozo, LAw AND Literature 53 (1931). For "presumptions of reliance" see Snyder, sipra note 4, at 131.

12 Menges v. Dentler, $33 \mathrm{~Pa} .495,500$ (1858).

13 Bowen, Francis Bacon 146 (1963). Said Cardozo, "One does not need to expatiate upon the value of certainty in a developed legal system." CARDozo, THE GROWTH OF THE LAW 3 (1924). And he stated, "What has once been settled by a precedent will not be unsettled overnight, for certainty and uniformity are gains not lightly to be sacrificed. Above all else is this true when honest men have shaped their conduct upon the faith of the pronouncement." Cardozo, PARAdOXES OF IEGAL Science 29-30 (1928); see Cardozo, The Nature of the Judicial Process 149-51 (1921). See also the remarks of Judge Jerome Frank in In re Barnett, 124 F.2d 1005, 1011 (2d Cir. 1942), and in Hammond-Knowlton v. United States, 121 F.2d 192, 204 (2d Cir.), cert. denied, 314 U.S. 694 (1941). But see Douglas, Stare Decisis, 49 Colum. L. Rev. 735, 747 (1949).

14 Von Moschzisker, a proponent of retroactivity, recognized that the hardship it entails "affords a strong argument in favor of adherence to precedent." Von Moschzisker, Stare Decisis in Courts of Last Resort, 37 HARv. I. REv. 409, 423-24 (1924). So too, Judge Fuld stated, "the courts have rightly been loath to announce new rules which would adversely affect transactions entered into in reliance on previously declared doctrines." Fuld, The Commissions and the Courts, 40 CORNELL L.Q. 646, 647 (1955). See also Freeman, The Protection Afforded Against the Retroactive Operation of an Overruling Decision, 18 CoLUM. L. REv. 230, 233 (1918); Kocourek \& Koven, supra note 3 , at 987 ; Mishkin, supra note 7.

Certainty "was the essential characteristic of, and the basic reason for, the common law doctrine of precedent." Goodhart, Precedent in English and Continental Lave, 50 L.Q. REv. 40, 60 (1934). Among other reasons, as Hamilton noted, "to avoid an arbitrary discretion in the courts, it is indispensable that they should be bound down by strict rules and precedents . . " THE FEDERALIST No. 78, at 510 (Mod. Lib. ed. 1941). See also the preface by Judge Cranch of the District of Columbia Circuit Court to the first volume of his Supreme Court Reports, 5 U.S. (1 Cranch) iii (1801).

15 Washington v. W. E. Dawson \& Co., 264 U.S. 219, 238 (1924) (Brandeis, J., dissenting).

16 See text accompanying notes $37 \& 38$ and note 38 infra.

172 Davis § 17.07, at 526-29. 
cretion is to offer the model, it should be employed with the severe self-restraint exhibited by the courts, with awareness that the model has some built-in limitations. For example, the courts have carved out certain exceptions from the area of retroactivity, notably for the situation in which an overruling decision would "affect contracts made or property acquired in reliance upon the decision overruled." 18 State courts in particular have "gone far in protecting rights acquired in reliance upon a previous decision," 19 and the winds of change are blowing in the federal courts. ${ }^{20}$ As Cardozo pointed out, "when the hardship is felt to be too great or to be unnecessary, retrospective operation is withheld." ${ }^{21}$ Some agencies have made it a practice to withhold retroactive operation where hardship might ensue, ${ }^{22}$ but others blithely ignore the "contract" exception, the Cardozo formulation and, indeed, all self-restraint.

Opposition to change is not my theme-self-evidently a legal system must be responsive to changing needs; I address myself rather to the manner of its accomplishment. In the administrative domain, it cannot be sufficiently stressed, agencies, unlike courts, enjoy power to make prospective changes by use of the legislative "rule-making" power. Were legislation "a sufficient agency of growth," said Cardozo, he would have been "half-ready" to put stare decisis in the Constitution "and to add thereto the requirement of mechanical and literal reproduction." ${ }^{23}$ Such was the value he attached to certainty and uni-

18 Snyder, supra note 4, at 130-31; accord, Kocourek \& Koven, supra note 3 , at 989. The expansion of the "exception" beyond the area of contract is detailed by Snyder, supra note 4, at 130-41. CARDOzo, THE GRowTH OF THE LAw 81-82 (1924), calls attention to Dean Pound's "fruitful generalization" that "certain branches of the law call in conspicuous measure for certainty and order, for an administration of justice that is strict and in a sense mechanical," among others, "matters of commercial law, and the creation incidents and transfers of obligations." Compare with such utterances the NLRB treatment of union agreements, at text accompanying notes $44-77$ infra.

19 Freeman, supra note 14, at 239; accord, Kocourek \& Koven, supra note 3, at 988-89; Snyder, supra note 4, at 130-32.

20 Safarik v. Udall, 304 F.2d 944, 949-50 (D.C. Cir.), cert. denied, 371 U.S. 901 (1962), refers to "a well-settled exception that courts ordinarily will give prospective effect only to a decision overruling prior decisions where persons have contracted, acquired rights, or acted in reliance on the prior decision, and the operation of the later decision retrospectively would result in substantial harm to such persons." See also Lyons v. Westinghouse Elec. Corp., 235 F. Supp. 526, 537 (S.D.N.Y. 1964).

21 Cardozo, The Nature of the Judicial Process 146-47 (1921). (Emphasis added.) The quotation is preceded by the statement that "in the vast majority of cases the retrospective effect of judge-made law is felt either to involve no hardship or only such hardship as inevitable where no rule has been declared." Ibid. (Emphasis added.)

22 Safarik v. Udall, 304 F.2d 944, 949 (D.C. Cir.), cert. denied, 371 U.S. 901 (1962), refers to the long-standing rule of the Department of Interior "not to give its... decisions retroactive effect, especially when to do so would adversely affect actions taken and rights and interests acquired by private persons on the faith of the earlier decisions and would inure to the benefit of other private persons." $C f$. 1 Davis $\$ 5.09$, at $352-54$.

23 Cardozo, The Growth of the Law 132-33 (1924). 
formity. Administrative agencies have in their own hands and under their control this very legislative "agency of growth," of correction of inadequate rules, and it is therefore not too much to require that the need for retrospective operation be demonstrated rather than airily assumed to be an essential attribute of administrative adjudication. ${ }^{24}$ As Linkletter v. Walker emphasized, there is a need to "weigh the merits and demerits [of retroactivity] in each case." 25 Let us now assay administrative retroactivity in light of the self-restraint wherewith retrospection has been employed by the courts and the availability of "legislative" power which agencies enjoy and courts do not.

\section{The Chenery Case}

Widely cited as the leading case for administrative retroactivity, SEC v. Chenery Corp. ${ }^{26}$ illustrates an inescapable "clarification of uncertain law" in a case of first impression rather than "a change in settled law." 27 Chenery did not involve a change of rule, for no rule had earlier been promulgated by regulation or decision. The SEC "had not previously been confronted with the problem of management trading during reorganization"; it was a "case of first impression," 28 and one that allegedly could not be handled by prospective regulation, for the Commission had before it an amendment to a corporate plan of reorganization which it was required to approve or reject. The Supreme Court said that the amendment had to be consistent with proper standards and that the SEC could not approve it if it concluded that the

24 Judge Friendly stated that agencies "are, and ought to be, much likelier to engage both in new departures and in alterations than the courts with their more limited 'molecular motions' . . ." and that "this makes it peculiarly important for them to take full advantage of their power to act prospectively, whether by rulemaking or adjudication." NLRB v. Majestic Weaving Co., 355 F.2d 854, 860-61 (2d Cir. 1966).

For facile assumptions that retroactivity should be the administrative norm, see Deluxe Metal Furniture Co., 121 N.L.R.B. 995, 1006-07 (1958) : "The judicial practice of applying each pronouncement of a rule of law to the case in which the issue arises and to all pending cases in whatever stage is traditional and, we believe, the wiser course to follow." There is no cognizance of judicial self-restraint in the premises, of judicial exceptions, or of the fact that the tide in general was running powerfully the other way. So too, in NLRB v. Local 176, United Bhd. of Carpenters, 276 F.2d 583, 586 (1st Cir. 1960), the court said, "If this determination of the Board was retroactive, it was no more so than whenever a court of law decides, on further consideration, to modify its earlier views."

25 Linkletter v. Walker, 381 U.S. 618, 629 (1965). In Chicot County Drainage Dist. v. Baxter State Bank, 308 U.S. 371,374 (1940), the Court stated:

The past cannot always be erased by a new judicial declaration. The effect of the subsequent ruling as to invalidity may have to be considered in various aspects.... Questions of rights claimed to have become vested, of status, of prior determinations deemed to have finality and acted upon accordingly, of public policy in the light of the nature both of the statute and of its previous application, demand examination.

26332 U.S. 194 (1947).

272 Davis $\$ 17.08$, at 538 .

28332 U.S. at 203. 
amendment "was inconsistent" with those standards "merely because there was no general rule or regulation covering the matter." 29 These considerations led the Ninth Circuit in NLRB v. Guy F. Atkinson Co. to distinguish Chenery because

there the Commission was confronted with the necessity of making an order relating to a corporate reorganization in respect to which it was its duty and obligation to attach appropriate conditions for approval. . . The Commission was operating under compulsion .....30

The fact that this was a case of "first impression," coupled with $\mathrm{Mr}$. Justice Jackson's vehement attack upon the "invalidity of retroactive lawmaking," 31 in which he was joined by Mr. Justice Frankfurter, lends special emphasis, when the case is presented in which the agency seeks to change an existing rule, to the Court's admonition. An administrative agency, it said,

unlike a court, does have the ability to make new law prospectively through the exercise of its rule-making powers [and therefore] has less reason to rely upon ad hoc adjudication to formulate new standards of conduct...

and that

the function of filling in the interstices of the Act should be performed, as much as possible, through this quasi-legislative promulgation of rules to be applied in the future. ${ }^{32}$

From this one might conclude with Professor Dodd that an agency's power "to act retrospectively by order in a particular case should be

29 Id. at 201. Professor Davis stated that

the Commission declared that a satisfactory rule could not be formulated.

But that statement is unconvincing, for even though widely varying details

and circumstances might go to the essence, a rule could be flexible in any

desired degree-it could forbid corporate managers to profit by purchase of the corporation's securities during the reorganization whenever the Commission finds such a purchase to be detrimental to investors, or it could prohibit such profit except when the Commission specifically approves. Apart from rule making, the Commission in this case, had it been sufficiently foresighted, might have mitigated the retroactive element by advance notice of what was contemplated. . . Unlike a court, a commission need not refrain from taking a position, or a tentative position, until the time comes for announcement of a decision in a particular case.

2 Davis \$17.08, at 540.

No more "foresight" by the Commission was called for than that which the Commission demanded from the reorganization managers, for the Commission stated, to borrow from Professor Davis, id. at 535, that "previous legal developments indicated a climate of opinion in which at least some reasonable men considered transactions of this character to be fraught with temptation and of dubious propriety," eminently the situation in which Professor Davis' suggested cautionary rule could have been issued.

30195 F.2d 141, 147 (9th Cir. 1952).

31332 U.S. at 213 (dissenting opinion).

32 Id. at 202. (Emphasis added.) 
confined within narrower limits than that of a court," 33 and, minimally, that a court should feel called on to inquire in a given case why it was not "possible" to "perform" the task through the "promulgation of rules to be applied in the future." But Chenery left the choice between ad hoc adjudication and rule making "primarily in the informed discretion of the administrative agency." 34 Little wonder that despite the Court's "pointed hint" to resort to rule making "as much as possible," the NLRB, for example, has left the rule-making procedure virtually untouched. ${ }^{35}$ For a regulation is binding on the administrator until it is replaced by another regulation, ${ }^{\mathbf{3 6}}$ which generally operates

33 Note, 56 Harv. L. Rev. 1002, 1005 (1943). Professor Davis stated:

A more persuasive dissenting opinion in the Chenery case might have been written by recognizing that the degree of the Commission's retroactive law making was substantially the same as that which has long been accepted in the judicial process, but by emphasizing that agencies should not necessarily be allowed to imitate courts in this respect. The chief difference is that agencies can use techniques not easily available to courts for avoiding or softening the retroactive element. One such technique is rule making. That a court, having no rule-making power, makes law retroactively through adjudication does not mean that an agency may leave its rule-making power unused and act only through adjudication no matter how serious may be the disadvantage of retroactive law making in the circumstances.

2 Davis $\$ 17.08$, at 540 . Thus far, a Daniel come to judgment. But Professor Davis apparently concludes that such an opinion should not have been written, because "for the courts to hold illegal, unfair, unauthorized or unconstitutional what are substantially the same methods of law development that are traditional in the judicial system may seem to many to be incongruous and impracticable." Id. at 541 .

To begin with, the "tradition" was being badly shaken by one attack after another and even as Professor Davis wrote it was waning. And it is more "incongruous" that agencies designed to escape the bonds of tradition, should adopt a harsh practice which the courts mistakenly believed they themselves were compelled to adopt. The view of the hypothetical "many," it seems to me, resembles the child's "he's doing it, why can't I?" And the answer is plain: undesirable practices should not be imitated. For me, relaxation of the bonds of "evidence" has proved to be "practicable" and I suggest that avoidance of retroactivity is no less so, as the example of the courts demonstrates.

34332 U.S. at 203.

35 See NLRB y. Majestic Weaving Co., 355 F.2d 854, 860 (2d Cir. 1966). This was not the first time that Judge Friendly had nudged the NLRB to turn to rulemaking procedure. See NLRB v. A.P.W. Prods. Co., 316 F.2d 899, 905 (2d Cir. 1963); Friendly, The Federal Administrative Agencies 50 (1962). See also NLRB v. E \& B Brewing Co., 276 F.2d 594, 598 (6th Cir. 1960), cert. denied, 366 U.S. 908 (1961).

36 Vitarelli v. Seaton, 359 U.S. 535, 539-40 (1959); Service v. Dulles, 354 U.S. 363, 388 (1957) ; GELLHORN \& BYSE, op. cit. supra note 1 , at 860-62.

If the rule is embodied in a regulation, the agency cannot change it retroactively by adjudication. Judge Jerome Frank, when Chairman of the SEC, summarized the law:

If the rule is clearly applicable, the administrative body may not refuse to apply the rule, merely because it finds the rule unwise. Thus, an administrative body, confronted with a general rule [of its own making], is like a court confronted with a specific statute. If the statute is valid and clearly applicable to the specific case, the court must apply it thereto without regard to its wisdom.

Consumers Power Co., 6 S.E.C. 444,477 n. 48 (1939) ; see Arizona Grocery Co. v. Atchison, T. \& S.F. Ry., 284 U.S. 370, 389 (1932); cf. Capital Airlines v. CAB, 171 F.2d 339 (D.C. Cir. 1948), cert. denied, 336 U.S. 961 (1949); NLRB v. A.P.W. Prods. Co., 316 F.2d 899, 906 (2d Cir. 1963) (dictum). 
prospectively, whereas the agencies have been encouraged by the courts to believe that existing adjudicatory rules may be retroactively changed without let or hindrance. As one court seductively phrased it, "the Board is not the slave of its rules," 37 and other courts have not been slow to pick up the catchy lyric. ${ }^{38}$ It is not uncharitable to surmise that the attractions of such adjudicatory "flexibility" have caused the charms of rule making to languish in desuetude.

The agency option under Chenery between proceeding by rule making or by individual ad hoc adjudication, I suggest, has been read too broadly. Chenery addressed itself to a "case of first impression," and it was in this context that the Court stated, "Not every principle essential to the effective administration of a statute can or should be cast immediately into the mold of a general rule. Some principles must await their own development, while others must be adjusted to meet particular, unforeseeable situations." 39 Precisely such a particular situation, the necessity of approving or rejecting a submitted plan of corporate reorganization, faced the SEC. But as Judge Friendly pointed out, "the problem of retroactive application has a somewhat different aspect in cases not of first but of second impression, where an agency alters an established rule defining permissible conduct which has been generally recognized and relied on throughout the industry that it regulates." 40 If the distinction drawn by Professor Davis between "a clarification of uncertain law" and "a change in settled law" ${ }^{41}$ is to be meaningful, retroactivity in a case of second impression, as Judge Friendly intimated, should meet more exacting requirements than in a case of first impression. And the Chenery admonition that the "function of filling in the interstices of the Act should be performed

37 NLRB v. Grace Co., 184 F.2d 126, 129 (8th Cir. 1950). The phrase has charitably been characterized as "offhand." GELLEORN \& BYSE, op. cit. supra note 1 , at 863 n.9.

38 Sun Oil Co. v. FPC, 256 F.2d 233, 239 (5th Cir.), cert. denied, 358 U.S. 872 (1958) ; Foreman \& Clark, Inc. v. NLRB, 215 F.2d 396, 410 (9th Cir.), cert. denied. 348 UU.S. 887 (1954); NLRB v. National Container Corp., 211 F.2d 525, 534 (2d Cir. 1954). Compare NLRB v. Pacific Gas \& Elec. Co., 118 F.2d 780, 789 (9th Cir. 1941): "since the Board has power to make the rules it has power to suspend them." Accord, NLRB v. Monsanto Chem. Co., 205 F.2d 763, 764 (8th Cir. 1953).

39332 U.S. at 202. The Court explained:

[P] roblems may arise in a case which the administrative agency could not reasonably foresee, problems which must be solved despite the absence of a relevant general rule. Or the agency may not have had sufficient experience with a particular problem to warrant rigidifying its tentative judgment into a hard and fast rule. Or the problem may be so specialized and varying in nature as to be impossible of capture within the boundaries of a general rule.

Id. at 202-03. Manifestly these tests ill suit a change in an existing rule, let alone a sixth change.

40 NLRB v. Majestic Weaving Co., 355 F.2d 854, 860 (2d Cir. 1966).

412 Davis $\$ 17.08$, at 538 . 
as much as possible" ${ }^{42}$ through rule making has redoubled force when an agency would change an existing rule. It is therefore a mistake to invoke Chenery for administrative "authority to adopt and reverse policy." 43 Whether the majority, which sought in Chenery to facilitate the handling of a unique situation in a case of first impression, would have regarded a retroactive reversal of an existing decisional rule as generously, not to mention a sixth reversal in a case of sixth impression, is at least questionable.

\section{The NLRB "Contract Bar" Rule: Six Retroactive Changes}

Retroactive adjudication by the NLRB has often been at the very antipodes from what was actually decided in Chenery. Contrast the Chenery "clarification of uncertain law" in a case of first impression with the NLRB "contract bar" rule that as of 1960 had been altered "no less than five times" in the Board's twenty-six year history," and in 1963 was changed yet again. ${ }^{45}$ Where in judicial history can one point to six retroactive swings of the pendulum by one court in twentynine years with respect to one and the same rule? ${ }^{46}$ And each of the six changes testified afresh that the prior solutions, a one-year, twoyear, three-year, two-year and then five-year bar had been found wanting. What is there in this history to inspire confidence that the latest replacement of the five-year bar by a two-year bar was the ultimate rich fruit of administrative "experience"? The five changes, to say the least, afford unpromising material from which to spell out a compulsion to make still another change harshly retroactive. And they call for some soul-searching in light of the Supreme Court's statement that

constant re-examination and endless vacillation may become ludicrous, self-defeating and even oppressive. Whether for better or for worse so far as the merits of the chosen course are concerned, a point may be reached at which the die needs

42 See text accompanying note 32 supra.

43 Optical Workers' Union v. NLRB, 227 F.2d 687, 691 (5th Cir. 1955), cert. dentied, 351 U.S. 963 (1956). (Emphasis added.)

44 The history of the change is recounted in Leedom v. International Bhd. of Elec. Workers, 278 F.2d 237, 242 n.20 (D.C. Cir. 1960).

45 General Cable Corp., 51 L.R.R.M. 1444 (1962) (three-year "contract bar"). 40 In his critique of Linkletter $v$. Walker, Mishkin states:

Ineluctable retroactivity would seem to operate as an "inherent restraint" on judicial law making because it compels the Court to confront in sharpest form the possible undesirable consequences of adopting a new rule, as for example, when it appears that application of the newly framed doctrine may result in imposing liability or other burdens on someone who acted in justified reliance on the old law.

Mishkin, supra note 7, at 70. Apparently awareness of the "inherent restraint" has eluded the NLRB. 
to be cast with some "finality." An opposition may thus develop between the right result and the final result."

A little background of the "contract bar" rule will facilitate consideration of the six changes. The "contract bar" rule protects a valid collective bargaining agreement for a given period against renewed union quarrels over representation. ${ }^{48}$ Such an agreement may justifiably be relied upon by the contracting union and employer to protect them from the "expense and turmoil" ${ }^{40}$ of a fresh election sought by a rival union. The Board developed the rule to accommodate the conflicting goals of the Wagner Act-to promote stabilization of wage rates and working conditions while assuring workers full freedom of association and designation of their own representatives. ${ }^{50}$ An important consideration in making a collective bargaining agreement "is its duration," and this is directly influenced by the "contract bar" rule.". Once such an agreement has been made, a "fundamental . . . statutory objective of industrial stability . . . has ostensibly been achieved." 52 True it is that at appropriate intervals employees must be permitted to register afresh their choice of representatives, ${ }^{53}$ and the availability of that option is insured by the "contract bar." But as a former NLRB General Counsel observed, "Every form of representative government must necessarily curtail freedom of choice for a period after a choice has been made... ."; ${ }^{54}$ and the "competing interest of contract

47 CAB v. Delta Air Lines, Inc., 367 U.S. 316, 321 n.5 (1961). Mr. Justice Brandeis stated that "it is usually more important that a rule of law be settled, than that it be settled right." Di Santo v. Pennsylvania, 273 U.S. 34, 42 (1927) (dissenting opinion, joined by Holmes, J.). See also Freeman, sispra note 14, at 231 . (1959).

48 Friedin, The Board, The "Bar," and the Bargain, 59 ColvM. L. REv. 61, 62

49 Leedom v. International Bhd. of Elec. Workers, 278 F.2d 237, 243 (D.C. Cir. 1960). Senator Taft referred to "a constant stirring up of excitement by continual elections." 93 CoNG. REC. 3838 (1947).

50 Van Arkel, Twenty Years of the NLRB: Unit and Contract Bar Problems in Representation Cases, 16 OHIO ST. L.J. 360 (1955).

51 Friedin, supra note 48, at 68 . "An employer, unwilling to grant all of a union's demands during a short period may be prepared to grant many over a longer term. A union, aware of the relevance of the duration of an agreement in the employer's calculation of costs, may trade them for benefits not otherwise obtainable during a short term." Ibid. Once negotiated, the "stability of the contract . . . is plainly a matter of crucial importance to the employer as well as to the contracting union. The contract bar rules, which can so directly affect the integrity of the agreement, are thereby bound to affect the parties during their negotiations." Id. at 62 .

52 Feldesman, Contract Bar to Representation Elections, 29 Geo. WASH. L. Rev. 450 (1960). The "signed agreement has been regarded as the effective instrument of stabilizing labor relations." H. J. Heinz \& Co. v. NLRB, 311 U.S. 514, 524 (1941).

53 Feldesman, supra note 52, at 451.

54 Van Arkel, supra note 50, at 377. In discussing the Board's reasoning, Mr. Justice Frankfurter said: "In the political and business spheres, the choice of the voters in an election binds them for a fixed time. This promotes a sense of responsibility in the electorate and needed coherence in administration. These considerations are equally relevant to healthy labor relations." Brooks v. NLRB, 348 U.S. 96, 99 (1954). 
stability required some limit on the employees' freedom to change representatives ...." 55 Since the making of a collective bargaining agreement unquestionably advances a major, if not the "underlying purpose," ${ }^{56}$ of the act, stable industrial relations or "industrial peace," and since "contract stability requires some limitation on the employees' freedom to change representatives," a limitation expressed in the existing "contract bar," it may be asked precisely what statutory interest requires the repeated retroactive disruption of such agreements. It is unsatisfying to be told that the "contract bar" is "a procedural rule which the Board in its discretion may apply or waive as the facts of a given case demand." ${ }^{57}$

A more sophisticated and thorough-going attempt to come to grips with retroactive changes of the "contract bar" rule was made in Leedom v. International Bhd. of Elec. Workers. ${ }^{68}$ There the issue was complicated by the lack of a statutory appeal so that the district court resorted to the principle that "retroactive application of new policy . . . constituted an abuse of discretion and therefore amounted to a deprivation of property without due process of law." ${ }^{69}$ The focus of discussion in the court of appeals, which rejected this view, ${ }^{60}$ was whether the change amounted to an invasion of a constitutional right. Whether a retroactive change of the "contract bar" rule amounts to an "abuse of discretion" presents a separate issue which can be profitably examined against the general background of retroactivity. The issue whether arbitrariness itself amounts to a denial of due process may be deferred for the moment. ${ }^{61}$

Leedom recognized that "antipathy to retroactive lawmaking by courts and legislatures has deep historical roots"; ${ }^{82}$ it noted the "fundamental unfairness of retrospective legislation," 83 the "vice inherent in retroactivity" in that "it tends to destroy predictability and

65 Friedin, supra note 48, at 63. And in NLRB v. Efco Mfg., Inc., 203 F.2d 458, 459 (1st Cir. 1953), it was said: "The Board has followed a general administrative policy of not entertaining a petition for certification while the employees concerned are covered by a collective bargaining agreement which is not approaching expiration. The objective is to encourage a reasonable stability in existing bargaining relationships."

56 Brooks v. NLRB, 348 U.S. 96, 103 (1954). "It may be doubted whether [holding an election in the face of an existing collective agreement] . . . 'encourages' collective bargaining." Van Arkel, supra note 50, at 360-61.

57 NLRB v. Grace Co., 184 F.2d 126, 129 (8th Cir. 1950); cf. GelinoRN \& Byse, Adaministrative Law: Cases and Comments 449 (1954 ed.).

58278 F.2d 237 (D.C. Cir. 1960).

$69 \mathrm{Id}$. at 239.

60278 F.2d at 239-40; accord, Local 719, Int1 Prod. Employees v. McLeod, 183

F. Supp. 790 (E.D.N.Y. 1960).

61 See text accompanying notes 115-19 infra.

62278 F.2d at 240 .

63 Ibid. 
to undercut reliance-both important aims of the law." ${ }^{84}$ The court then pointed out that "the need for predictability must compete with the need for change . . . the virtues of stability must be balanced with the benefits of progress." "6x And it sought to apply the Chenery test: " "[The evils of retroactivity] must be balanced against the mischief of producing a result which is contrary to statutory design and equitable principles." "66 Thus the problem was placed in its proper setting, though I would emphasize that the "need for change" can be satisfied by resort to prospective rule making.

The Board did not deny in Leedom that "the Union may have relied upon the existing law when negotiating the contract" and that "retroactive application of the new bar may work a hardship upon the Union." ${ }^{67}$ Instead it argued that

(1) to apply the bar in futuro would, in some cases, preclude the Board from putting its new policies fully into effect for as long as five years from the date the change was announced;

(2) simultaneous administration of the new and old rules would create an "administrative monstrosity." 68

Prospective operation is always bought at the cost of such disparity since every time that a rule is announced prospectively there arises a disparity in treatment between transactions under the old rule and the new. ${ }^{69}$ By the Board's logic retroactivity would become very nearly inescapable. That which is the norm cannot be "monstrous," i.e., abnormal and unnatural. Of the same nature is the Board's argument that it may have "to wait up to five years [in some instances] to put its new policies into full effect." 70 That too is always a consequence of prospective operation: existing transactions are left untouched. The decisive issue rather is why those transactions should be disrupted

\section{Ibid.}

65 Ibid.

68 Id. at 240-41. Judges Miller and Burger did not join in this part of the opinion; and, if we are to infer that they dissented therefrom, it is a surprising dissent from established principles.

67 Id. at 241 . The Board brazenly urged that the many changes in the past put the parties "on notice not to rely on the earlier bar." Id. at 242 . Could one anticipate after years of "experimentation" that "change" would be never-ending? And what of traditional trust in "law" made by government?

68 Id. at $242-43$.

69 Professor Currier furnished a striking example of the unjust disparity which would result were the overruling of Wolf v. Colorado, 338 U.S. 25 (1949), by Mapp v. Ohio, 367 U.S. 643 (1961), confined prospectively, Currier, Time and Change in Judge-Made Law; Prospective Overruling, 51 VA. L. REv. 201, 201-02 (1965). Yet the Supreme Court did just that in Linkletter. Experience has shown, or at least the courts have been persuaded, that greater injustice flows from retroactivity than from the disparity occasioned by prospective operation.

70 278 F.2d at 243. 
when disruption is admittedly injurious. Professor Currier, who emphasized the competing value of equality of treatment, the obverse of the "disparity" the Board would avoid, and who advocated that retroactive effect be given to the overruling of a certain constitutional decision, nonetheless stated that "if a person does in fact act in reliance upon contemporaneous law legitimating certain conduct, the strongest kind of case can be made out for protecting such reliance." 71

In Leedom, the court gave a slightly different twist to the Board's arguments, reasoning that the five-year

drag on the administrative process would tend to destroy its flexibility. Administrative flexibility is, after all, one of the principal reasons for the establishment of regulatory agencies. It permits valuable experimentation and allows administrative policies to reflect changing policy views. ${ }^{72}$

But "valuable experimentation"-and after five "experiments," one may ask "How long, Oh Lord"-can also be prospective, without the cost of unfairness, hardship and repeated unsettlement of the law. ${ }^{73}$ "Flexibility" is given ample play by the availability of choice between retro-

71 Currier, supra note 69, at 256. And, he stated, "a change in property law fairly cries out for prospective overruling." Id. at 242 .

In Leedom, the court noted that "courts have often upheld statutes which cut off or modified private contracts where it appeared that the legislation sought to attain social purposes of greater importance than predictability and reliance." $278 \mathrm{~F} .2 \mathrm{~d}$ at 240. It does not appear that this remark was aimed at the judicial "exception" from retroactivity for contracts. At any rate, the "gold clause" and "mortgage moratorium" cases, Norman v. Baltimore \& O.R.R., 294 U.S. 240 (1935) ; Home Bldg. \& Loan Ass'n v. Blaisdell, 290 U.S. 398 (1934), appropriately sustained statutes which retroactively overrode contracts in order to stem the tide of the depression. But the need for a sixth change of the "contract bar" is incommensurate with the imperative need to shore up a tottering economy against calamitous insistence upon payment in gold as per contract, or to stay mortgage foreclosures upon land of farmers made penniless by a national disaster.

72278 F.2d at 243 . The writer of the opinion, Judge Bazelon, reached this conclusion "with considerable difficulty." Id. at 240 .

73 See text accompanying note 41 supra. Compare Judge Wyzanski's aphorism, "The administrator is expected to treat experience not as a jailer but as a teacher" Shawmut Ass'n v. SEC, 146 F.2d 791, 796-97 (1st Cir. 1945), with Professor Peck's comments, in what Judge Friendly called a "penetrating article," FrIENDLY, THE Federal Administrative Agencies 43 n.27 (1962):

[W] hile the ad hoc approach may have been the necessary and proper means for developing early contract bar principles, it would hardly appear necessary or even appropriate to a current reformulation of those principles. . . The necessity of continuing the experimental approach, with its undesirable consequences upon existing relationships, appears to vanish after twelve years of experiment and experience with a problem; the Board accumulated a wealth of basic data upon which broad principles and general rules could be formulated with a certainty that formerly was lacking. In short, this was not one of those instances where, in the words of the Supreme Court, an ad hoc approach, with its necessarily retroactive application could be justified .... 70 YaLE L.J. 729, 756 (1961). 
active and prospective operation. ${ }^{74}$ It is not essential to regard retroactivity like a fire alarm which must be sounded from time to time to demonstrate its readiness. "Flexibility" is merely a tool, not an end. As such, its "value and validity reside in what proceeds from .. . [it] ; consequences, not antecedents, supply meaning and verity." 75 The virtue of administrative flexibility therefore resides in how it is employed, and for present purposes the crucial question is whether the agency should exercise its "flexible" powers retrospectively because some overriding purpose outweighs the hardship and unfairness that will result. The "final principle of selection . . . is one of fitness to an end." 76 The Board's answers-avoidance of an "administrative monstrosity" and the alleged need to coordinate all agreements at once (the court's "drag on the administrative process") - prove too much, for they dictate in almost every case that prospective operation be shelved altogether. Of course, I do not argue for a frozen, immutable practice, but rather that a departure from the "wise usual policy" of avoiding retroactive hardship be justified by something more than a flexing of administrative muscles merely to demonstrate their flexibility, particularly in a case that falls within the well-known judicial exception for existing contracts. ${ }^{77}$

\section{Desirable Retroactivity Illustrated}

At the opposite pole from the "contract bar" cases are situations which more or less plainly demand retrospective operation and which highlight the differentiation between reasonable and unreasonable exercise of discretion. In Certified Color Indus. $v$. Secretary of Health, ${ }^{78}$ the act authorized the Secretary to list coal tar colors "which are harmless" and to certify batches of such colors. The Secretary revoked a certificate which had permitted the use of certain coal tar colors in foods, cosmetics and drugs, and quite properly construed the

74 While Chairman of the SEC, Judge Jerome Frank stated:

The existence of a power to amend old rules and make new ones [via rule making] permits an administrative body to achieve flexibility without disregarding the provisions of a rule which it has adopted and which stands unchanged. In view of this power, an existing but inadequate rule may be remedied, without ignoring its clear language and without, as a result, bringing the administrative process into disrepute.

Consumers Power Co., 6 S.E.C. 444, 457 (1939).

75 Cardozo, 55 N.Y. State Bar Ass'N Rep. 263, 294 (1932).

76 Cardozo, The Nature of the Judictal Process 103 (1921); see also id. at 119; Cardozo, The Growth of the Law 80 (1924).

77 Professor Feldesman noted "the inviolability of contracts recognized generally by our jurisprudence," in his discussion of the NLRB "contract bar," Feldesman, supra note 52 , at 450 , but overlooked the judicial exception carved out from retroactivity for contracts.

78283 F.2d 622 (2d Cir. 1960). 
statute to authorize the withdrawal of a certificate of harmlessness when facts became known which establish that the color is not harmless. ${ }^{79}$ To maintain the prior issuance was irrevocable in these circumstances would be to imperil the public health. There can be no vested right to sell food that contains harmful rather than harmless colors; protection of the public far outweighed any hardship to the sellers.

Of the same order, though perhaps the equities were more evenly balanced, is Atlas Tack Corp. v. New York Stock Exch. ${ }^{80}$ The SEC delisted the Atlas stock and Atlas complained of retroactive Exchange standards. Prior to 1955 the Exchange made no reference to "average net earnings," and Atlas alleged that

in reliance on this known and existing policy, it opened and operated, at the request of the United States Government, a magnesium foundry . . . ; that its losses in 1952, 1953 and 1954 were due to this operation. It further argues that, if it had known its failure to earn at least $\$ 200,000$ in each of the years 1952, 1953 and 1954 would later jeopardize its right to have its securities listed on the Exchange, it would not have undertaken the aforementioned expansion. ${ }^{81}$

Undeniably there was hardship which flowed both from the action undertaken at government request and the absence of any cautions by the Exchange. But the court, following the Chenery "balancing" formula, stated that "any retroactive effect of the instant rule should be weighed against the protection afforded present and potential investors by delisting securities not suitable for trading on the Exchange." 82 Parenthetically, this was not a case of a "change" in an existing rule but rather the announcement of a rule in a "case of first impression." The conclusion that protection of investors required the disclosure of losses notwithstanding the extenuating circumstances under which they were incurred, and that this weighed more heavily in the scales than the consequent hardship inflicted on Atlas, cannot, in my judgment, be stamped as unreasonable, even though reasonable men might differ as to the weight to be attributed to the competing factors.

\section{Announcements of Changes of Jurisdiction}

Retroactive announcements by the NLRB of changes in existing rules respecting the jurisdiction it will exercise in the future exhibit so erratic and capricious a course as to shake confidence in its judgment

$79 I d$. at 626.

80246 F.2d 311 (1st Cir. 1957).

81 Id. at $317-18$.

82 Id. at 318 . 
that retroactivity was essential. The Board has changed a jurisdictional requirement retroactively in order to corral a violator; ${ }^{88}$ it has made changes in mid-stream when the consequence was to free one whom its trial examiner had already found to be a violator. ${ }^{84}$ It has refused to make a jurisdictional change retroactive, ${ }^{85}$ and, without adequate explanation, has made such changes retrospective. ${ }^{86}$ It has eschewed retroactivity on the ground that it was unfair and inequitable, ${ }^{87}$ and it has all but ignored those elements in other decisions.

If ever a situation cried out for resort to rule making, it is an announcement that the Board will no longer take jurisdiction of cases that had prompted action in the past or that it will take jurisdiction where it hitherto had declined to do so. Such declarations speak, and should speak, to the future, a basic criterion of a "rule" or "legislative" act as contrasted with the application of existing law to past events, an earmark of adjudication. ${ }^{88}$ Here the reasons for retroactivity are at their nadir and, therefore, the Board ought to be required to make the strongest showing why the change must be retrospective. Consideration of a few cases will illuminate the problem.

Callous use of retroactivity is strikingly illustrated by Pedersen v. $N L R B,,^{89}$ in which the Second Circuit aptly labeled resort thereto a "species of entrapment." ${ }^{\circ 0}$ In response to a Board subpoena Pedersen

83 See text accompanying notes 93-95, 97 and note 98 infra.

84 See text accompanying notes 89-92, 99 infra.

85 See, e.g., C. A. Braukman, 94 N.L.R.B. 1609 (1951).

${ }^{86}$ See text accompanying notes $93-95,97$ and note 98 infra.

87 In C. A. Braukman, 94 N.L.R.B. 1609, 1611 (1951), the Board declined to apply new jurisdictional standards retroactively and to assert jurisdiction where it had formerly refused to do so, because of its "obligation to respect our prior decisions . - [and] a desire for fair play. It would be inequitable now to hold Respondent liable" for activities that occurred at a time when the Board "in effect advised Respondent" that it would not assert jurisdiction over its operations. This responds to traditional criteria for avoidance of retroactivity.

88 Prentis v. Atlantic Coast Line Co., 211 U.S. 210, 226 (1908). This was the approach adopted by the House and Senate Reports in explaining "rules" during the enactment of the Administrative Procedure Act. Rules "formally prescribe a course of conduct for the future rather than merely pronounce past or existing liabilities." S. Doc. No. 248, 79th Cong., 2d Sess. 254, 197 (1946). And Chairman Walter explained to the House: "In rule making an agency is not telling someone what his rights or liabilities are for past conduct or present status under existing law. Instead, in rule making the agency is prescribing what the future law shall be so far as it is authorized to act." Id. at 355. The Administrative Procedure Act defines "rule" as a statement of "future effect." 5 U.S.C. \$551(4) (Supp. -).

The Board itself explained that after a time it abandoned an "ad hoc approach" to drawing jurisdictional standards because "experience has shown . . . that jurisdictional guide lines thus established are extremely time and energy consuming to apply, and result in confusion and uncertainty as to exactly where the dividing line will be drawn in particular cases . ..." Siemons Mailing Serv., 122 N.L.R.B. 81, 83 (1958). In fact, therefore, the Board was issuing regulations, which should be treated as binding until replaced prospectively. See note 36 supra.

89234 F.2d 417 (2d Cir. 1956).

O0 Id. at 419 . 
testified against his employer, who thereupon discharged him in violation of the statutory prohibition of discharge grounded on such testimony. The employee filed a complaint and the trial examiner, after hearing, recommended reinstatement. At this point the Board issued new jurisdictional requirements, decided that the employer's business did not meet them and dismissed the complaint. Here, as the court emphasized, "the act which resulted in petitioner's loss of employment was not [merely] induced by Board action; rather it was compelled by the Board." 91 In colloquial terms, the Board forced Pedersen to climb out on a limb and then sawed it off, concomitantly releasing a violator of the statute. The court concluded that the refusal to exercise jurisdiction was arbitrary and capricious and that the Board's action was "unjust and intolerable." ${ }_{22}$ The fact that the Board could conclude in this case that administrative exigencies overrode the hardship and injustice caused by the Board itself furnishes good reason for close scrutiny of the reasons it advances in each case for retrospective decision.

Factually, NLRB v. Pease Oil $\mathrm{Co}^{93}$ is quite different. The employer had discharged employees for union activity in violation of the act and was ordered by the Board to reinstate them with back pay. No retroactive interpretation of the act was required to make out the violation; instead the Board took jurisdiction after it had earlier announced that it would not, i.e., it changed the prior "jurisdictional standard" whereunder the Board would not hear complaints relating to businesses having as little effect upon interstate commerce as that of respondent. The court rejected the argument that respondent had "relied" upon the earlier jurisdictional standards on the ground that this "reliance" was simply an expectation that it might violate the law with impunity. A statute, it said, "imposes a duty of obedience unrelated to the threat of punishment for disobedience." 94 Or, as another court phrased it, Board announcements that jurisdiction would not be asserted did "not license a company that comes within the purview of the Act to commit unfair practices at will." 95 Strictly speaking this is true; nevertheless there is no blinking the fact that to announce that certain violators will not be prosecuted is to encourage violation, so that subsequent prosecution smacks of a "species of entrapment." The fact that Judge Madden, formerly a distinguished chairman of the

\section{Ibid.}

82 Id. at 420.

93279 F.2d 135 (2d Cir. 1960).

94 Id. at 137 . 1960).

95 NLRB v. Guernsey-Muskingum Elec. Co-op., Inc., 285 F.2d 8, 11 (6th Cir. 
NLRB, dissented in Pease Oil Co., partly because he felt that the retroactive assumption of jurisdiction was lacking in "fair play," ${ }^{96}$ and that although the Sixth Circuit sustained such a shift, it noted that "it might not be "cricket" " to make such a change, ${ }^{97}$ raises the question whether the courts too mechanically have permitted the Board to engage in a retroactive hunt for violators whom it led to think were immune. 88

It is not as if the instinct for fair play must yield to an inexorable administrative pattern for retroactive sanctions against violators, for Pedersen glaringly illustrates that the Board has blown both hot and cold. There a violator who was properly before the Board was turned loose by a retroactive relinquishment of jurisdiction, even though the consequence was to leave high and dry an employee who had testified under Board compulsion. And Pedersen does not stand alone. In Optical Workers Union v. $N L R B,{ }^{\text {,9 }}$ the union, having satisfied existing jurisdictional limitations, had a hearing before the trial examiner, who found that the employer had engaged in unfair labor practices. The Board then dismissed the complaint because the employer's volume of business did not satisfy newly announced jurisdictional standards. Once again the Board relinquished existing jurisdiction and freed a violator who was properly before the Board under an existing jurisdictional announcement which in effect cautioned that violators would be prosecuted. Retroactivity was thus invoked in Pedersen and in Optical to shield a forewarned violator, from which it may be deduced that the element of "violation" little influenced the Board's thinking, or for that matter that of the court, which said in Optical "there is no sound reason why standards cannot be applied retroactively." 100 When Optical and similar cases ${ }^{101}$ are compared

98279 F.2d at 140 .

97 NLRB v. West Side Carpet Cleaning Co., 329 F.2d 758, 760 (6th Cir. 1964). Compare the Board's own limitation of back pay awards "in consideration of its prior position" that it had no jurisdiction. NLRB v. Baltimore Transit Co., 140 F.2d 51, 55 (4th Cir.), cert. denied, 321 U.S. 795 (1944).

98 See NLRB v. West Side Carpet Cleaning Co., supra note 97; NLRB v. Guernsey-Muskingum Elec. Co-op., Inc., 285 F.2d 8, 11 (6th Cir. 1960); NLRB v. Jones I Lumber Co., 245 F.2d 388, 391 (9th Cir. 1957); NLRB v. Gottfried Baking Co., 210 F.2d 772, 781 (2d Cir. 1954) ; NLRB v. Kobritz, 193 F.2d 8, 12 (1st Cir. 1951), petition to vacate denied, 201 F.2d 156 (1st Cir. 1953). The statement in Guernsey-Muskingum that "a prohibitory law does not become effective only when there is danger of a violator being caught," $285 \mathrm{~F} .2 \mathrm{~d}$ at 11, and in Jones Lumber that the Board's jurisdictional announcements "could not limit the jurisdiction conferred by Congress," 245 F.2d at 391, seem to me to misconceive the issue. Of course, the Board cannot alter what Congress provides. But "it is not required by the statute to move on every point, it is merely enabled to do so." NLRB v. Indiana \& Mich. Elec. Co., 318 U.S. 9, 18 (1943), and the issue is whether it should be precluded from moving because of its conduct.

90227 F.2d 687 (5th Cir. 1955), cert. denied, 351 U.S. 963 (1956).

100 Id. at 691.

101 Pedersen v. NLRB, 234 F.2d 417 (2d Cir. 1956); Local 12, Progressive Mine Workers v. NLRB, 189 F.2d 1 (7th Cir.), cert. denied, 342 U.S. 868 (1951). 
with Pease, it is apparent that the Board itself has removed the urgency of a retroactive hunt for violators, and worse, that it proceeds without rhyme or reason, the worst possible basis for injurious retroactivity. Indeed, the capricious prosecutions themselves suggest arbitrariness. ${ }^{102}$ Minimally, the Board's repeated judgment that retroactive punishment of violators is inconsequential takes the steam out of judicial statements that Board announcements that it will not exercise jurisdiction cannot be regarded as a license for violation.

\section{Hardship and Arbitrary Retroactivity}

In SEC v. Chenery Corp., ${ }^{103}$ a case of administrative first impression, the Court stated that retroactivity is condemned if its "ill effect" is not outweighed by the "mischief" to the public interest. ${ }^{104}$ A stiffer standard might be expected in a change-of-rule case; yet Leedom, as we have seen, held that conceded hardship-abrogation of a union

102 See NLRB v. Pease Oil Co., 279 F.2d 135, 138 (2d Cir. 1960) : "[E]nforcement has been denied where the Board has appeared to the court to have been arbitrary and capricious in refusing to consider other complaints of a similar nature to the one before the court."

Without "a uniform practice and method of procedure for the commencement and conduct of contests" it "is perfectly obvious that even-handed justice to all litigants can [not] be impartially administered . . . ." Germania Iron Co. v. James, 89 Fed. 811, 813, 818 (8th Cir. 1898). "What a farce," it was said in Howe v. Parker, 190 Fed. 738, 757 (8th Cir. 1911), "the attempt to secure and protect rights in any judicial or quasi-judicial tribunal must become if its rules and decisions are imposed or applied to each case as it arises at the arbitrary will of the officer who presides." Cf. McKay v. Wahlenmaier, 226 F.2d 35 (D.C. Cir. 1955); United States ex rel. Knauff v. McGrath, 181 F.2d 839, 841 (2d Cir. 1950), vacated as moot, 340 U.S. 940 (1951) ; Hammond-Knowiton v. United States, 121 F.2d 192, 204 (2d Cir.), cert. denied, 314 U.S. 694 (1941) ; Thompson v. Spear, 91 F.2d 430, 434 (5th Cir. 1937) cert. denied, 302 U.S. 762 (1938); International Business Mach. Corp. v. United States, 343 F.2d 914, 919-20 (Ct. Ci.), cert. denied, 382 U.S. 1028 (1965) ; Berchem v. Reconstruction Fin. Corp., 191 F.2d 922, 924-25 (Emer. Ct. App. 1951).

For cases that have sustained "inconsistent" treatment, see 2 DAvIs $\$ 17.07$, at 528-30. Their rationalizations, to my mind, amount to little more than abdication of judicial responsibility. "One of the most fundamental social interests is that the law shall be uniform and impartial. There must be nothing in its action that savors of prejudice or favor or even arbitrary whim or fitfulness. Therefore in the main there shall be adherence to precedent." Cardozo, THE NATURE of THE Judicial Process 112 (1921); see also id. at 33-34. The view that "perhaps the courts should not impose upon the agencies standards of consistency of action which the courts themselves customarily violate," 2 DAvis $\$ 17.07$, at 530, calls for correction, rather than slavish imitation, of judicial error. For "it will not do to decide the same question one way between one set of litigants and the opposite way between another. 'If a group of cases involves the same point, the parties expect the same decision. It would be a gross injustice to decide alternate cases on opposite principles." Cardozo, The Nature of the Judictal Process 33 (1921); see also Cardozo, ParaDOXES of LEgAL Scrence 97 (1928). Of course it is always open to a tribunal to determine that there is a sufficient difference in the facts at bar to warrant a deviation from a principle or the application of another.

103332 U.S. 194 (1947).

104 "Retroactivity must be balanced against the mischief of producing a result which is contrary to a statutory design or to legal and equitable principles. If that mischief is greater than the ill effect of the retroactive application of a new standard, it is not the type of retroactivity "which is condemned by law." Id. at 203. 
agreement-was outweighed by the need for administrative "flexibility." 105 Nevertheless, it is safe to say, for example, that given visible pecuniary hardship, decisional retroactivity will be deemed arbitrary. NLRB v. Guy F. Atkinson Co. ${ }^{106}$ an oft-cited case, is illustrative. An employer turned to a union for help in recruiting for an Atomic Energy Commission construction project and then entered into an agreement with the union. At union request an employee who failed to pay union dues was discharged. The Board had not as yet announced the rule that where a work force was expanding rapidly, an agreement at an early stage would not constitute the union the appropriate bargaining unit. After the discharge and ensuing complaint, the Board abandoned its permissive attitude, ${ }^{107}$ held that the discharge constituted an unfair labor practice and ordered the reinstatement of the employee with payment of back pay. In short, the Board retroactively penalized the employer for acting pursuant to a union agreement that was valid when made and that advanced a prime objective of the act-industrial peace. Justifiably the court refused to allow retrospective effect to the change because, following the Chenery formula, retroactivity worked

hardship upon respondent altogether out of proportion to the public ends to be accomplished. The inequity of such an impact of retroactive policy making upon a respondent innocent of any conscious violation of the act, and who was unable to know, when it acted, that it was guilty of any [misconduct] . . is manifest. It is the sort of thing our system abhors. ${ }^{108}$

105 See text accompanying note 72 supra.

100195 F.2d 141 (9th Cir. 1952).

107 The Board also changed its earlier rule that it would not take jurisdiction of the construction industry, but the case is generally associated with the retroactive banning of a union.

108195 F.2d at 149. Writing in 1958, Professor Davis stated, "The Atkinson case is an unreliable authority, for many similar cases go the other way. . . " 2 DAvis $\$ 17.03$, at 508 , and that "the various cases opposed to the Atkinson case represent stronger authority and may be preferable in their understanding of principle." $I d$. $\$ 17.09$, at 543 . It is true that most of the cases do sustain the retroactive assumption or relinquishment of jurisdiction, though I should question whether they exhibit a better "understanding of principle." See text accompanying notes 96-102 supra. But on the more important branch of the case, the retrospective imposition of a penalty for conduct that was innocent at the time, the Atkinson view is shared by other courts. See cases cited note 109 infra; NLRB v. Local 41, Teamsters Union, 225 F.2d 343, 348 (8th Cir. 1955).

In NLRB v. Majestic Weaving Co., 355 F.2d 854, 860 (2d Cir. 1966), Judge Friendly stated that judicial "hackles bristle still more when a financial penalty is assessed for action that might well have been avoided if the agency's changed disposition had been earlier made known .... "Leedom purported to distinguish Atkinson because there "the Board made conduct actionable which theretofore had not been actionable." 278 F.2d at 243. Compare NLRB v. Guernsey-Muskingum Elec. Co-op., Inc., 285 F.2d 8, 11 (6th Cir. 1960) ("only if it creates an inequitable situation by its change of policy can its right and duty to enforce the law be curbed by the court"); Pedersen v. NLRB, 234 F.2d 417 (2d Cir. 1956); NLRB v. Daboll, 
There are other decisions to the same effect, ${ }^{109}$ one of which will be quoted at length because the court so clearly responded to traditional judicial criteria. In NLRB v. Local 41, Teamsters Union, ${ }^{110}$ a retroactive change in the Board's position toward employee seniority provisions was rejected. Earlier Board decisions had sustained "identical" union seniority provisions, but in the Local 41 case the Board outlawed them and ordered the union to make whole employees who had sustained losses as a result of prior seniority priorities under its agreement. Not doubting the "soundness of the new view," the court said,

we do not believe that the spirit of the Act . . . entitles the Board, on engaging in such an about-face . . . to brand a party as being guilty of an unfair labor practice in having made such a contract provision, while the Board's express holding that the provision is a proper one under the Act has remained unrenounced.

[I]t does not seem to us to make either legal or common sense to say that the Board's rulings are wholly without any sanctity under the Act as a guide for employer or Union conduct, but that the Act intends that anyone who relies upon and uses the Board's rulings as a basis for his actions shall be left subject to entrapment and branding as the perpetrator of an unfair practice in what he has thus done,

216 F.2d 143, 144 (9th Cir. 1954), cert. denied, 348 U.S. 917 (1955) ("the courts will not disturb that discretion unless the Board has acted in violation of previously prescribed standards upon which the employer had a right to rely, and the disregard of which would lead to an injustice."). NLRB v. Pease Oil Co., 279 F.2d 135, 139 (2d Cir. 1960), adverted to the Atkinson pivotal fact that "the party charged with an unfair labor practice was "innocent of any conscious violation of the act." "See the Guernsey-Muskingum statement that Atkinson and Pease "are not in conflict." 285 F.2d at 11.

Professor Davis himself has stated that "probably the courts should sometimes intervene to protect against unfairness resulting from an administrative adjudication which retroactively changes law on which a party has relied." 2 Davis $\$ 17.09$, at 544.

108 In NLRB v. E \& B Brewing Co., 276 F.2d 594 (6th Cir. 1960), cert. denied, 366 U.S. 908 (1961), a "hiring hall" case, the Board ordered reinstatement of an employee with back pay because of an alleged unfair labor practice. The court said, "the contract, perfectly legal and valid according to the Board's settled rule at the time it was made, has now, retroactively, been adjudged per se illegal for want of one of the Board's three protective clauses demanded under its new ruling." Id. at 600 . Citing Atkinson, the court concluded that the retrospective change would "work hardship upon respondent altogether out of proportion to the public ends to be accomplished." Ibid. In another "hiring hall" case, NLRB v. Local 176, United Bhd. of Carpenters, 276 F.2d 583, 586 (1st Cir. 1960), the court rejected the Board's order of "disgorgement of dues, requiring the union to refund to every member who had obtained employment the dues he had paid," because the union "conduct was recognized as unlawful only after it had occurred." In a similar case, MorrisonKnudsen Co. v. NLRB, 275 F.2d 914, 918 (2d Cir. 1960), cert. denied, 366 U.S. 909 (1961), the court declared that the Board's retrospective requirement of reimbursement was "inappropriate and arbitrary." See also Yellow Transit Freight Lines v. United States, 221 F. Supp. 465, 468, 470 (N.D. Tex. 1963), an ICC case. See also notes 21 \& 108 supra.

110225 F.2d 343 (8th Cir. 1955). 
if the Board thereafter chances . . to depart from one of its previous positions and rulings. ${ }^{111}$

In sum, the cases demonstrate that an agency does not enjoy untrammeled discretion to make retroactive decisions, and that this discretion, like all discretion, must not be exercised in arbitrary fashion. Arbitrary action or abuse of discretion-the terms are used interchangeably ${ }^{112}$-describes the unreasonable, oppressive use of delegated power. ${ }^{113}$ The inquiry, it has been said in the labor relations area, is whether the "situation and circumstances clearly show an abuse of discretion, that is arbitrary action not justifiable in view of such situation and circumstances." 114 Before I turn to the quantum of hardship that is required to make out arbitrariness, let me venture a word on the "constitutional" question that was central to the Leedom case. If arbitrariness be found, it is clear that it constitutes a denial of due process. The Supreme Court has epitomized "due process" as the "protection of the individual against arbitrary action." ${ }^{115}$ It has stated that the Constitution condemns "all arbitrary exercise of power," 116 that "delegated power, of course, may not be exercised arbitrarily," "117 that "there is no place in our constitutional system for the exercise of

111 Id. at 348 .

112 "[A]buse of discretion" is "arbitrary action not justifiable" in the circumstances. NLRB v. Guernsey-Muskingum Elec. Co-op., Inc., 285 F.2d 8, 11 (6th Cir. 1960). "Discretion. . . is abused when the judicial action is arbitrary, fanciful or unreasonable ...." Delno v. Market St. Ry., 124 F.2d 965, 967 (9th Cir. 1942); see Gonzalez v. Freeman, 334 F.2d 570, 580 (D.C. Cir. 1964); Western Airlines v. CAB, 184 F.2d 545, 551 (9th Cir. 1950).

113 For various definitions see Berger, Adninistrative Arbitrariness and $J_{n d i c i a l}$ Review, 65 Colum. L. REv. 55, 82-83 (1965). In Wong Wing Hang v. Immigration \& Naturalization Serv., 360 F.2d 715, 719 (2d Cir. 1966), Judge Friendly stated that action is abuse of discretion which, if taken "without a rational explanation, inexplicably departed from established policies...."

114 NLRB v. Guernsey-Muskingum Elec. Co-op., Inc., 285 F.2d 9, 11 (6th Cir. 1960). See also note 102 supra. C $f$. NLRB v. Majestic Weaving Co., 355 F.2d 854, 861 (2d Cir. 1966), where Judge Friendly stated that "where for fifteen years the Board considered conditional negotiation consistent with the statutory design 'the ill effect of the retroactive application of a new standard' so far outweighs any demonstrated need for immediate application to past conduct . . . as to render the action "arbitrary." "

The focus of inquiry has been "whether the Board abused its discretion." NLRB v. Guernsey-Muskingum Elec. Co-op., Inc., 285 F.2d 9, 11 (6th Cir. 1960); cf. NLRB v. Daboll, 216 F.2d 143, 144 (9th Cir. 1954). In NLRB v. Pease Oil Co., 279 F.2d 135,138 (2d Cir. 1960), it was said that "cases where courts have held that the Board abused its discretion fall into three clearly defined categories . . . ." Atkinson, which the court cited, did not fall within any of the "three categories," and indeed "abuse of discretion" is endlessly varied.

115 Ohio Bell Tel. Co. v. Public Util. Comm'n, 301 U.S. 292, 302 (1937). Arbitrary application of a statute is unconstitutional. Yick Wo v. Hopkins, 118 U.S. 356, 373-74 (1886). Arbitrarily to cause an alien to be deported is incompatible with due process. The Japanese Immigration Case, 189 U.S. 86, 101 (1903).

118 ICC v. Louisville \& N.R.R., 227 U.S. 88, 91 (1913).

117 FCC v. Schreiber, 381 U.S. 279, 292 (1965). 
arbitrary power." 118 Power is not delegated to administrators to make oppression possible. ${ }^{119}$

\section{The Measure of Hardship}

The Chenery formula, framed in a case of "first impression," called for a balancing of the "ill effect of the retroactive application of a new standard" against the "mischief of producing a result which is contrary to a statutory design or to legal and equitable principles." 120 When courts hold that agencies are free to change their rules retroactively at will, they ignore this "balancing" formula altogether. ${ }^{121}$ Apart from Leedom, which balanced the need for "flexibility" against conceded "hardship," 122 the courts have indulged in little refined dissection of the factors involved. Any attempt at "weighing" must first take into account that the scales should be more heavily weighted against retroactivity in a "change of rule" case than in a case of "first impression" such as Chenery. Second, "weighing" requires close examination of the "mischief" that is expected to flow from rejection of retroactivity rather than assumption that exclusion of retroactivity will be injurious. For as Cardozo stated, if hardship is "unnecessary, retrospective operation is withheld." ${ }^{123}$ Third, "hardship" itself need not be weighed in an apothecary's scales unless the opposing considerations are finely balanced.

The measure of hardship, to my mind, has been unduly complicated. To begin with, the measure, contrary to an intimation in Leedom, has not been evidence of "gross injustice." 124 The words "gross injustice" were employed in Tidal Oil Co. v. Flanagan" ${ }^{125}$ to "explain" Gelpcke v. City of Dubuque, ${ }^{126}$ which Tidal Oil in fact repudiated on "diversity jurisdiction" grounds. In Gelpcke, the Court was faced with a state court decision that overruled a prior state court construction of a state statute. Municipal bonds had been purchased in reliance on the earlier decision which held them valid. Despite the

118 Garfield v. United States ex rel. Goldsby, 211 U.S. 249, 262 (1908). Our institutions "do not mean to leave room for the play and action of purely personal and arbitrary power." Yick Wo v. Hopkins, 118 U.S. 356, 370 (1886). See also Bank of Columbia v. Okely, 17 U.S. (4 Wheat.) 235,244 (1819).

119 See Berger, Administrative Arbitrariness and Judicial Review, 65 Couvas.

L. REv. 55, 56-57 (1965).

120332 U.S. at 203 ; see note 104 supra.

121 See notes $37 \& 38$ sipra and accompanying text.

122 See text accompanying notes $67 \& 72$ silpra.

123 See text accompanying note 21 supra.

124278 F.2d at 241 . Although the court purported to state a criterion for judicial retroactivity, the framework of the case was administrative retroactivity, and I am therefore evaluating the "gross injustice" phrase in that context.

125263 U.S. 444, 452 (1924).

12668 U.S. (1 Wall.) 175 (1864). 
"diversity" rule that courts will follow a state court construction of a state statute which overrules an earlier construction, ${ }^{127}$ the Supreme Court felt compelled to adopt the earlier construction "upon the plainest principles of justice," ${ }^{128}$ notwithstanding that the consequence was to warp the "diversity" rule. Gelpcke affords an extreme example of the lengths to which a court will go to avoid hardship when reliance upon an earlier rule is undercut. ${ }^{129}$ The retrospective invalidation of bonds purchased in reliance upon an existing adjudicatory rule seems no more "gross injustice" than the retroactive impairment of a "collective bargaining agreement," unless we are to conclude out of hand that the "expense and turmoil," for both union and employer, of an election sought by a rival union, bears no comparison to the hurt suffered by the holder of an invalidated bond. The existing union runs the risk of unexpected displacement; the employer risks renegotiation with a possibly more obdurate rival union. If anything, the bitterness of industrial strife, the losses that flow from jurisdictional squabbles, the statutory and social goal of "industrial peace," make out a stronger reason for protection of a union agreement. ${ }^{130}$ Nor is it self-evident that the financial hardship consequent upon an order for back pay to an employee in the Atkinson and Pedersen cases is incommensurate with the hardship that flows from the unexpected union contest with a rival in the teeth of an existing agreement. Judge Friendly purported to distinguish Leedom, where a retroactive change in the "contract bar" rule was sustained, saying that "a decision branding as 'unfair' conduct stamped 'fair' at the time a party acted, raises judicial hackles considerably more than a determination that merely . . shortens the period in which a collective bargaining agreement may bar a new election," ${ }^{131}$ but one trusts that he was judiciously confining himself to the case at bar. For the branding of "unfair" upon practices earlier stamped "fair" seems no more culpable than nullification of a contract admittedly stamped valid when made.

While it is probably true, as Judge Friendly stated, that judicial "hackles bristle... more when a financial penalty is [retroactively]

127 Leffingwell v. Warren, 67 U.S. (2 Black) 599, 603 (1862). Gelpcke recognized that it "is the settled rule of this court, in such cases, to follow the decisions of the State courts," 68 U.S. at 206, but it purportedly carved out an exception. See $i d$. at 205.

128 Id. at 206.

129 The Court's revulsion to retroactivity is underscored by its remark, "We shall never immolate truth, justice, and the law, because a state tribunal has erected the altar and decreed the sacrifice." 68 U.S. at 206-07.

130 Professor Peck adverts to the "inevitably unsettling effect that pending elections have upon labor relations and production." Peck, The Atrophied Rule-Making Powers of the National Labor Relations Board, 70 YALE L.J. 729, 739 (1961).

131 NLRB v. Majestic Weaving Co., 355 F.2d 854, 860 (2d Cir. 1966). 
assessed," 132 the fact remains that in rejecting retroactivity courts have repeatedly acted upon what they said were the "plainest principles of justice," ${ }^{133}$ and that hardship is but one element that needs to be weighed in consideration of retroactivity. Judicial emphasis on financial hardship tends to obscure that other elements are also entitled to weight: there is the affront to the sense of fair play, unfairness, the betrayal of reliance on existing law by people who are entitled to order their transactions in reliance on it, and the unsettlement of past transactions to the detriment of certainty whilst making discrimination possible. All of these deserved to be weighed against flimsy agency explanations for resort to retroactive decisions, the more so as the impact of retroactivity has from time to time evoked expressions of judicial abhorrence. Certainly the reasoning of the back pay cases emphasized financial hardship no more than the other elements. Instead, therefore, of starting with built-in assumptions that retroactivity is the norm which the victim must overthrow, I suggest that retrospection starts and should start with a handicap.

\section{A Suggested Presumption Against Retroactive Administrative Decisions}

If we are to take seriously statements that there is a deep-rooted "antipathy to retrospective law-making," 134 that retrospective operation is fundamentally "unfair," 135 it is reasonable to require a demonstration that it is indeed "the lesser evil," 136 before it is permitted. This in turn can be translated into a presumption against a retroactive change of rule, the obverse of Cardozo's postulate that "certainty and regularity have at least a presumption in their favor." ${ }^{137}$ When an agency seeks retroactively to substitute a new decisional rule for an existing one, it should take the laboring oar on review, all the more because what it seeks to do is generally regarded with disfavor. If it cannot muster substantial reasons for the allowance of retroactivity, it should be confined to prospective change. The courts would still be

132 Ibid.

133 Gelpcke v. City of Dubuque, 68 U.S. (1 Wall.) 175, 206 (1864). For additional cases see Snyder, Retrospective Operation of Overruling Decisions, 35 ILL. L. REv. 140-42 (1940).

134 See text accompanying note 62 supra. Hochman refers to the "hostility to retroactive legislation [which] will lead the Court to hold unconstitutional a statute whose retroactive application serves 'no discernible public purpose." "Hochman, The Supreme Court and the Constitutionality of Retroactive Legislation, 73 HARv. L. REv. 692, 697 (1960).

135 See text accompanying note 63 supra.

136 Retroactivity was chosen as "the lesser evil" in Addison v. Holly Hill Fruit Prods., Inc., 322 U.S. 607, 622 (1944).

137 Cardozo, 55 N.Y. State Bar Ass'n Rep. 263, 284 (1932). 
called upon to weigh the competing values that are at stake in any given case. And the fact that some agencies make it a rule to withhold retrospective effect from their decisions shows that it is practical to do so. ${ }^{138}$ A presumption, for example, would serve to correct the whimsical, erratic course pursued by the NLRB by compelling it to weigh more seriously whether the public interest really requires a retroactive decision and, better, to demonstrate the need to a reviewing court. Such a presumption might go far to rationalize administration and to dispel the confusion which now runs rife through the cases. It would put teeth into the "antipathy to retroactive law-making," and it would put motive power behind the Court's exhortation in Chenery to employ rule making "as much as possible."

What of the dictum in Chenery, it may be asked, which leaves the choice between rule making and adjudication in the "informed discretion" of the agency. That statement was made in a "case of first impression"; given an adjudicatory change in an existing rule it should be read against the Court's declaration in 1833 that administrative "usage" may not be retrospectively changed and "must be considered as binding on past transactions," ${ }^{139}$ and its 1872 statement that contracting parties "have a right" to rely on existing law and "nothing can justify us in holding them to any other rule." 140 Then too, the entire judicial attitude toward retroactivity has undergone a marked transformation since Chenery. When Chenery was decided in 1947, only fifteen years had elapsed since Mr. Justice Cardozo's opinion in Great No. Ry. v. Sunburst Oil \& Ref. Co ${ }^{141}$ burst like a meteor before a profession still under the spell of the declaratory theory. ${ }^{142}$ Courts,

138 See note 22 supra.

139 United States v. Macdaniel, 32 U.S. (7 Pet.) 1, 15 (1833).

140 Olcott v. The Supervisors, 83 U.S. (16 Wall.) 678, 690 (1872).

141287 U.S. 358 (1932).

142 See, e.g., Ruppert v. Ruppert, 134 F.2d 497, 500 (D.C. Cir. 1942) ; Peterson v. John Hancock Mut. Ins. Co., 116 F.2d 148, 151 (8th Cir. 1940); City of Chelsea v. Richard T. Green Co., 318 Mass. 85, 87, 60 N.E.2d 351, 352 (1945).

In 1940, Professor Snyder, despairing of "succeeding where the mighty have failed, accept[ed] the [declaratory] theory," Snyder, silpra note 133, at 122, saying that "it enlists habitual modes of thought", $i d$. at 152, and within that framework sought to synthesize the declaratory theory with a denial of retroactive operation to overruling decisions. Id. at 145-53.

Chenery must also be weighed in light of the Supreme Court's subsequent admonition in Universal Camera Corp. v. NLRB, 340 U.S. 474, 490 (1951), "that the Administrative Procedure Act and the Taft-Hartley Act direct that courts must now assume more responsibility for the reasonableness and fairness of Labor Board decisions ... Congress has imposed upon them responsibility for assuring that the Board keeps within reasonable grounds." (Emphasis added.)

It is questionable whether the agencies can lay claim to "special competence" to determine whether retroactivity is unfair. "We deal with a problem which courts have frequent occasion to consider and upon which we think it cannot be said that the board or commission has superior opportunity for knowledge." NLRB v. Guy F. Atkinson Co., 195 F.2d 141, 151 (9th Cir. 1952): 
it will be recalled, felt themselves wedded to retroactivity because of their attachment to the declaratory theory. Thenceforth a "daringly experimental" court could confine its decisions to prospective operation. Chenery was decided, therefore, in an atmosphere where retroactivity was still the norm, and its recognition of the possibility of choice in a case of first impression between prospective and retrospective operation carried forward the Sunburst innovation. With the advent of Linkletter $v$. Walker, ${ }^{143}$ the skies have cleared. No longer is retroactivity viewed as a necessary concomitant of adjudication; to the contrary, it is to follow only after a weighing of relevant factors. That shift of judicial opinion calls for reconsideration of the whole problem of retroactive administrative adjudication.

Even before Linkletter was decided, the Second Circuit, per Judge Medina, said,

there are certain general policy considerations that we think make it generally undesirable to give retroactive effect to overruling decisions, except under the most compelling circumstances. ${ }^{144}$

This formulation is but an offshoot of a broad principle that played a greater role at the inception of our government than it does in administrative circles today, the salutary principle that government, as was said in Anderson v. Dunn, ${ }^{145}$ should employ "the least possible power adequate to the end proposed." 146 Or, as James Wilson earlier phrased it, "every wanton, or causeless, or unnecessary act of authority . . . is wrong, and unjustifiable, and tyrannical . . ." 147 It is not too much to ask that when governmental action may be injurious, when it smacks of "unfairness," when it defeats just reliance on existing decisional rules, when it disturbs the certainty that feeds the roots of the law and fosters discrimination, an agency should carry the burden of proving that it is truly "necessary." 148

143381 U.S. 618 (1965); see note 7 and text accompanying note 25 supra.

144 United States ex rel. Angelet v. Fay, 333 F.2d 12, 21 (2d Cir. 1964). (Emphasis added.)

14519 U.S. (6 Wheat.) 93 (1821).

$146 \mathrm{Id}$. at 105.

1472 Wruson, Works 393 (Andrews ed. 1896). Compare Mr. Justice Brandeis' statement that the "right to be let alone" is "the most comprehensive of rights." Olmstead v. United States, 277 U.S. 438, 478 (1928) (dissenting opinion).

Wilson had been one of the most active framers of the Constitution, and he "had done most of the actual drafting work for the Convention's Committee of Detail." 2 CRosskey, Politics AND THE CONSTITUTION 1040 (1953). In 1789 his explanation of the Constitution to the Pennsylvania Ratification Convention was cited in the First Congress as that of the "celebrated Mr. Wilson." 1 ANNals of Cong. 577 (1789). He became a Justice of the Supreme Court.

148 Compare the statement by Cardozo at text accompanying note 21 supras, 